Blackwell Companion to Buddhist Philosophy, Steven Emmanuel (ed.), Chichester: Wiley-Blackwell, pp. 320-330, 2013.

\title{
Buddhist Philosophy of Logic
}

\author{
Koji Tanaka ${ }^{1}$ \\ Department of Philosophy \\ University of Auckland \\ k.tanaka@auckland.ac.nz
}

\begin{abstract}
Logic in Buddhist Philosophy concerns the systematic study of anumāna (often translated as inference) as developed by Dignāga (480-540 c.E.) and Dharmakīti (600-660 c.E.). Buddhist logicians think of inference as an instrument of knowledge (pramāna) and, thus, logic is considered to constitute part of epistemology in the Buddhist tradition. According to the prevalent 20th and early 21 st century 'Western' conception of logic, however, logical study is the formal study of arguments. If we understand the nature of logic to be formal, it is difficult to see what bearing logic has on knowledge. In this paper, by weaving together the main threads of thought that are salient in Dignāga's and Dharmakiti's texts, I shall re-conceive the nature of logic in the context of epistemology and demarcate the logical part of epistemology which can be recognised as logic. I shall demonstrate that we can recognise the logical significance of inference as understood by Buddhist logicians despite the fact that its logical significance lies within the context of knowledge.
\end{abstract}

\section{Logic in Buddhist Philosophy}

Logic in Buddhist Philosophy, as we understand it in this chapter, concerns the systematic study of anumāna (often translated as inference) as developed by Dignāga (480-540 c.E.) and Dharmakīti (600-660 c.e.). Buddhist logicians think of inference as an instrument of knowledge (pramāna) and, thus, logic is considered to constitute part of epistemology in the Buddhist tradition. The focus of

\footnotetext{
${ }^{1}$ Many thanks go to Parimal Patil and Tom Tillemans for their extensive comments on an earlier version of this chapter.
} 
this chapter is on the tradition of Buddhist philosophy called pramānavāda which is concerned mainly with epistemology and logic. Thus, we are not concerned with various reasoning patterns that can be discerned in the writings of Buddhist philosophers; for example, when the Mādhyamika philosopher Nāgārjuna presents an argument in terms of catuskoti (four 'corners': true, false, both, neither). ${ }^{2}$ Nor are we concerned with lists of 'rules' for debates, such as the ones contained in the Indian $v \bar{a} d a$ (debate) literature and Tibetan bsdus grwa, though debates are important aspects of Indo-Tibetan Buddhist intellectual life. ${ }^{3}$

This chapter contains a discussion of the philosophy of logic that is attributable to Buddhist logicians. I will attempt to make sense of the Buddhist conception of the nature of logic by weaving together the main treads of thought that are salient in Dignāga's Pramānasamuccaya (and his autocommentary Pramānasamuccayavrtti) and Dharmakīrti's Pramānaviniścaya and Pramānavārttika. The exegetical studies of these texts and other texts recognised as belonging to the pramānavāda tradition are extensive but not exhaustive. The collection of historical data and the close reading of these texts are important tasks. In this chapter, however, we step back from the texts and examine (or reexamine) what 'inference' or 'logic' might mean for Buddhist logicians. ${ }^{4}$ I will sketch the Buddhist conception of the nature of logic by uncovering some of the presuppositions that underly the thoughts expressed in Buddhist logic texts.

\section{The Role of Inference in Epistemology}

Epistemology in the Buddhist philosophical tradition is generally concerned with instruments or sources of knowledge. What we know is considered to depend on how we know. That is, what we are warranted to be aware of depends on how we come to be aware of it. So, in order to understand what we know, Buddhist philosophers investigate the sources which give rise to warranted awareness (pramā).

Buddhist logicians identify two sources of knowledge: perception (pratyaksa) and inference (anumāna). Perception is said to be an immediate contact with particulars without any mediation of conception (which is considered to involve universals). There are two standard examples used to illustrate inference. In one

\footnotetext{
${ }^{2}$ There is a large number of secondary literature written about catuskoti. See, for example, Robinson (1957) and Ruegg (1977). For treatments of catuskoti using contemporary logical machinery, see Garfield and Priest (2003), Priest (2010), Tillemans (1999) ch. 9 and Tillemans (2009).

${ }^{3}$ For a discussion of bsdus grwa logic, see Tillemans (1999) ch. 6.

${ }^{4}$ For studies of Dignāga's works, see, for example, Hattori (1968) and Hayes (1988). For booklength studies of Dharmakīrti's works, see, for example, Dreyfus (1997) and Dunne (2004). For brief accounts of Dharmakīrti's life and works, see Steikellner (1998) and Tillemans (2011). See also Gillon (2011) for a brief discussion of Buddhist logic in a larger historical context.
} 
standard example, when we are aware that there is smoke on a mountain, we may infer that there is fire on that mountain. When we become aware of the presence of fire on the mountain in this way, that awareness is said to be warranted by inference and, thus, it counts as knowledge. In another example, we may become aware of the presence of a tree by inferring from our awareness that there

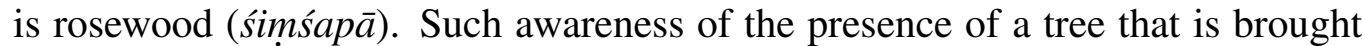
about by inferential cognition is said to be warranted and, thus, it is ascribed the status of knowledge.

Dignāga explains that the purpose of his texts - the foundational texts for the Buddhist epistemological and logical tradition — is to refute his opponents' views on the instruments of knowledge as well as to establish his own view as correct. ${ }^{5}$ Once inference is shown to be an instrument of knowledge, it is also shown to serve as an instrument for producing a cognition that can be ascribed the status of knowledge. Hence, inference can be thought to result not only in awareness that inference is an instrument of knowledge, but also in awareness of the truths of Buddhist thought.

Buddhist logicians recognise two contexts in which inference can be used as an instrument of knowledge. On the one hand, it can be used as an instrument for becoming aware of soteriological truths, such as the four noble truths, by themselves. This is called 'inference for oneself' (svārthānumāna). On the other hand, inference can be used as an instrument in dialectical engagements with opponents. In this context, inference serves as a tool for showing that the opponents' views are mistaken and to demonstrate that Buddhists' own views are correct in dialectic practice. This is called 'inference for others' (parārthānumāna). Thus, inference has a function directed at oneself and a function directed at others. ${ }^{6}$

\section{Logic or Epistemology?}

If we understand inference as a source of knowledge, it must be assumed that a certain relationship holds between inference and knowledge. In particular, it must be assumed that inference has a direct impact on one's knowledge state. As is implicit in the standard examples, inference subsumes three elements which might be thought to be distinct. One element of inference in the standard examples is the awareness of smoke or rosewood. This is the cognitive state prior to the involvement of the inferential cognitive process. The second element is the inferential cognitive process which moves cognition from awareness of smoke or rosewood to awareness of fire or tree. The third element is the resulting cognitive state, that is, awareness of fire or tree. These elements of Buddhist logic may strike some

\footnotetext{
${ }^{5}$ See Pramānasamuccayavrtti 1.10-1.13, translated in Hattori (1968) pp. 23-24.

${ }^{6}$ See Kellner (2004), Krasser (2001) and Patil (2009) ch. 6.
} 
as problematic given that 'inference' (or logic in general) is often understood as not having any bearing on knowledge. Some may even consider them to show that there is no logic in the Buddhist tradition (as we will see below). I will consider this issue before going on to explicate how Buddhist logicians understand inference in the context of epistemology.

According to the 'Western' conception of logic prevalent since the twentieth century, logical study is the formal study of arguments. An argument consists of premises and a conclusion (or conclusions). A study of logic is considered to be a study of the (syntactic) form of the relationship between the premises and a conclusion. If an argument has the form: $A$ and $A \supset B$ (if $A$ then $B$ ), therefore $B$ (modus ponens), for example, then the argument which instantiates this form is said to be valid. The form that an argument instantiates may also capture a subsentential (sub-propositional) structure. For example, an argument may have the following form: $\exists x \forall y R x y$ (Something $R$ s everything), therefore $\exists x R x x$ (Something $R$ s itself). Any argument which has this (sub-sentential) form is also said to be valid.

Western logicians disagree about which forms of argument should count as valid. (Strict) Aristotelian logicians regard the above sub-sentential structure (first-order structure) invalid as it is not one of the syllogisms that Aristotle identified. Intuitionistic logicians reject as invalid the form: $\neg \neg A$ (it is not the case that A is not the case), therefore $A$, as they interpret negation in terms of the failure to find a proof, and, thus, a failure to find a negative proof doesn't tantamount to a success of finding a positive proof. Paraconsistent logicians - whose logics have recently been applied to the study of reasoning involving catușkoti - may regard modus ponens invalid. If $A$ were both true and false, then $A$ and $A \supset B$ would be true (since $A$ would also be false) while $B$ might be only false. ${ }^{7}$

Which forms of argument should count as valid is evidently a contentious matter. Nonetheless, there is one thing that contemporary (western) logicians share in common - namely, the idea that logic is concerned with the forms of arguments. An argument is said to be valid if it instantiates a valid argument form. It is important to notice that, for contemporary logicians, the specific contents of the premises and the conclusion are irrelevant to logical study. The main focus of logical study is with the mathematical structures that satisfy valid argument forms rather than a concern with what the argument is about. ${ }^{8}$

\footnotetext{
${ }^{7}$ Paraconsistent logicians reject modus ponens which is formulated in terms of 'material conditional' $\supset$. $A \supset B$ is said to be true if and only if $A$ is false or $B$ is true. Some paraconsistent logicians introduce different accounts of the conditional, usually relevant conditionals, which validate modus ponens. For an introduction to paraconsistent logics, see, for example, Priest and Tanaka (2009).

${ }^{8}$ This 'orthodox' conception of logic is, in fact, a combination of the views on the nature of logic held by several logicians. It was Kant who argued for the view of logic according to which
} 
If we understand the nature of logic to be formal in this way, it is difficult to see what bearing logic has on cognitions that result in knowledge. Consider the following argument: there is smoke on a mountain, and if there is smoke on a mountain then there is fire on that mountain, therefore there is fire on that mountain. This argument has the form of modus ponens and, thus, it is formally valid. Now, assume that we know that there is smoke on the mountain and that where there is smoke there is fire, but we don't know that there is fire on the mountain. It seems that we ought to come to reason so that we know that there is fire on the mountain. However, what is the role of the validity of modus ponens in this reasoning? In order to think of modus ponens itself as having an impact on our cognitive activity, it wouldn't be sufficient for modus ponens to be, in fact, valid: we would have to be aware of the validity of modus ponens. We would also have to be aware that if an argument has a valid form, then we would have to infer the conclusion of the argument. But, in order to have this awareness, we would also have to be aware that if we are aware that 'if an argument has a valid form, then we have to infer the conclusion of the argument', then we would have to infer the conclusion. But, then, we would also have to be aware that ... ad infinitum. It seems that the form of the argument is not sufficient for thinking that there is fire on the mountain. ${ }^{9}$

The difficulty of accounting for the relationship between valid forms of arguments and knowledge can also be illustrated by examining what kind of cognitions are, in fact, involved in order to acquire new knowledge. We most likely infer that there is fire on a mountain if we are aware that there is smoke on that mountain and that where there is smoke there is fire. But, that is because awareness that there is fire on a mountain is consistent or coherent with what we already know, and not because cognitive activity involved in inferring that there is fire on a mountain has the form of modus ponens. When we acquire new knowledge by means of inferential cognitions, it is not the form of an argument (or reasoning) that forces us to infer the conclusion but the consistency (or coherency) of what we are aware of that moves us to cognise in a certain way. Hence, it seems that knowledge of the validity of an argument form is not even a necessary condition for knowing that there is fire on a mountain based on what we already know. ${ }^{10}$

Faced with these difficulties in accounting for the significance of epistemology in formal logic, we have (at least) two options in our attempt to understand

logic is abstracted from the objects of cognition. It is this view which became the main stream in the modern development of logic. See his Lectures on Logic. Translations of some of Kant's lectures on logic can be found in Young (1992). However, the account presented here is largely a model-theoretic account due to Tarski. See, for example, Tarski (1936).

${ }^{9}$ For the difficulty of this kind, see Carroll (1895), though the point of Carroll's discussion is moot.

${ }^{10}$ For a discussion of this kind, see Harman (1986). 
the role that inference (anumāna) is said to play in Buddhist epistemology. One is to suggest that the study of anumāna is not a study of logic at all (and, thus, it is misleading to translate it as 'inference'). After all, anumāna is an instrument for acquiring knowledge and, as such, it is an epistemological, not a formal, apparatus. Thus, according to this suggestion, there is no logic in Buddhist epistemology; there is just epistemology. ${ }^{11}$ It would follow that, strictly speaking, there is no Buddhist philosophy of logic.

This is not the only way in which we can respond to the above difficulties, however. Alternatively, we can re-conceive the nature of logic in the context of epistemology and demarcate the logical part of epistemology which can be recognised as logic. ${ }^{12}$ To think of an inference simply as a formal matter is to think of it as having logical significance independent of the cognitive act which can be characterised as inferential. If we think that logic is only about argument forms, it is difficult to understand the impact of inference on cognitive activities. However, we can understand inference as having logical significance within certain cognitive acts of inferring (or cognition which acts inferentially). Thus, according to this suggestion, we can focus on the nature of the role that inferential cognition plays. This is not to say that the form in which such a cognition takes place cannot be ascertained. It does suggest, however, that the form of a cognition is not what is at issue for Buddhist logicians.

Which of these two suggestions is most faithful to the Buddhist tradition is a controversial matter that I shall not attempt to settle in this chapter. If we are to elucidate Buddhist philosophy of logic, however, we must assume that we can recognise logic as part of the Buddhist study of anumāna (inference). Based on this (defeasible) assumption, I present what I take to be the conception of logic assumed by Buddhist logicians. Since logic is conceived in the context of epistemology, the Buddhist conception of logic must be unique (at least in comparison with twentieth- and early twenty-first-century Western orthodoxy). If so, this chapter does not merely present the way in which Buddhist logicians understand the nature of the object of their study, it also makes an important contribution to the philosophy of logic in general in that it develops an alternative to the conception of logic as purely formal in nature. ${ }^{13}$

\footnotetext{
${ }^{11}$ See, for example, Siderits (2003).

${ }^{12}$ I believe that this is the option taken by, for example, Matilal (1998), Mohanty (1992) and Tillemans (1999).

${ }^{13}$ In fact, despite the fact that logic is standardly understood to be formal in the sense that it doesn't have any bearing on knowledge, a study of the history of logic reveals that epistemological considerations often framed the development of logic. See, for example, Macbeth (2005) and Hylton (2005) for discussions of logical development by Frege and Russell — two of the founding figures of modern logic - respectively. Generally, the (western) history of logic is much more complicated than what many scholars of Buddhist logic assume. In fact, it lacks the uniformity that is often assumed when they appeal to (western) logical apparatus. See, for example, Gold-
} 


\section{The Elements of Inference}

Buddhist logicians hold that, by inference, one seeks to establish for oneself or for others the presence of what is to be proven (sādhya) in a particular locus (paksa) on the basis of the presence of an inferential reason (hetu) at that locus. For example, to use a standard example, when one sees smoke (inferential reason) on a particular mountain (locus), one may infer that there is fire (what is to be proven) on that mountain.

For an inference to count as 'valid' or an instrument of knowledge, the inferential reason must satisfy the triple conditions (trairūpya). There are mainly two interpretations of these triple conditions: ontological and epistemological. According to the ontological interpretation (which seems the more common interpretation), they can be presented as follows. (1) What is identified as the inferential reason must be present in the locus in question. This means, in our example, that smoke must be present on the mountain in question. This implies that a cogniser is, in fact, in a situation where there is smoke on the mountain. The second and third conditions are called pervasion (vyāpti). (2) The inferential reason must be present in at least one similar case (sapaksa) - a locus where what is to be proven is present. ${ }^{14}$ For example, smoke must be present in a kitchen with a wood-burning stove. (3) The inferential reason must not be present in any dissimilar case (vipaksa) - a locus where what is to be proven is absent. For example, smoke must not be present in a misty lake. The reason given for a thesis to be proven by inference must satisfy these triple conditions to count as an instrument of warranted awareness (i.e., knowledge).

According to (a strong form of) the epistemic interpretation, the triple conditions can be presented as follows: (1) the inferential reason must be known to occur in the locus, (2) the inferential reason must be known to occur in a similar case, and (3) the inferential reason must be known not to occur in dissimilar cases. $^{15}$

The difficulty of reconciling the ontological and epistemological interpretations is due to the epistemic context in which inference must be understood. In order to properly understand inference in epistemic contexts, we cannot think of these two interpretations mutually exclusive. According to the ontological in-

barb (1979), MacFarlane (2000) and van Heijenoort (1967).

${ }^{14}$ This is the formulation of Dignāga. Dharmakīti modifies the second condition as: the inferential reason must be present in at least one similar case and only in similar cases. See Potter (1969).

${ }^{15}$ The secondary literature on the triple conditions is extensive. See, for example, Franco (1990), Katsura (1983), Katsura (1984), Oetke (1994a), Patil (2010), Tillemans (1999) ch. 5 as well as several papers in Katsura and Steinkellner (2004). The majority of the secondary literature seems to present ontological interpretations. For epistemological interpretations, see Oetke (1994b) p. 846 and Patil (2009) pp. 66ff. 
terpretation, it is a fact that the triple conditions are satisfied. This fact can be appealed to as evidence for justifying one's awareness of the presence of fire on a mountain, for example. That is, if it can be demonstrated that one's awareness of fire can be characterised by the triple conditions, then that awareness, not its form but its content, can be given the status of knowledge by appealing to the fact about the satisfaction of triple conditions. This means that the triple conditions function as the standard of evaluation for what counts as knowledge. If one accepts this ontological interpretation, however, it is difficult to understand how the triple conditions have bearing on the acquisition of knowledge. Just as the validity of an argument form is not sufficient for coming to have knowledge, the fact that there is a justification doesn't seem to be enough for one to acquire knowledge. ${ }^{16}$ If we are to think that the triple conditions serve as a means of knowledge, they must contain the epistemic fact about one's having knowledge. Hence, if we are to understand the role that inference plays in epistemological contexts, we need to accommodate both intepretations. ${ }^{17}$

\section{Buddhist Conception of Logic}

Our discussion in the previous section suggests that inference is both ontological and epistemoplogical. As an instrument of warranted awareness, inference must warrants or justifies one's awareness but must also be instrumental in moving one's cognitive state to another cognitive state.

Consider, again, our example of smoke and fire on a mountain. Suppose that one is in a situation where there is smoke on a particular mountain. In order for awareness of fire on that mountain to be warranted, smoke must co-occur or must be co-located with fire on the mountain in the same way that smoke co-occurs with fire in a kitchen. However, smoke on a mountain must never co-occur with fire in a misty lake despite the fact that it may look as though there is smoke on the lake and, thus, there may be a mistaken 'appearance' of fire in the lake. Supposedly, these are the facts about the elements of inference. It may be difficult to establish that these facts, in fact, obtain. Nonetheless, if they are presented as facts, one can appeal to them in order to justify the inferential awareness of the presence

\footnotetext{
${ }^{16}$ For a discussion of the need for the epistemologisation of the triple conditions, see Tillemans (2004).

${ }^{17}$ One way to reconcile these two interpretations is to think of Buddhist logicians as being internalists about justification. That is to say that, for Buddhist logicians, the basis for the justification lies within one's cognition. This internalist characterisation of Buddhist epistemology is given in Arnold (2005) ch. 2. I shall put aside this internalist interpretation of Buddhist epistemology. In this chapter, I attempt to accommodate both ontological and epistemological interpretations without resorting to internalist epistemology. For a discussion of internalist/externalist epistemology as applied to Buddhists (and Nyaiyāyikas), see Patil (2009).
} 
of fire on the mountain based on the awareness of the presence of smoke on that mountain.

For pervasion between inferential reason and what is to be proven to have any cognitive grip, however, it has to be expressed to us in an intelligible manner. For example, I would not be cognitively moved at all by the mere fact that there is fire where there is smoke, unless that fact places some demand on my cognition. Nor would my cognition be stimulated to produce awareness of the presence of fire if I am simply perceiving smoke on a mountain. An immediate, perceptual awareness of smoke is not, of itself, enough for awareness of the presence of fire to warrantably occur. In order for cognition to be warranted and a cognitive process required such that certain awareness is brought about, we must connect the concept smoke with fire in a cognitively robust relation. By making a conceptual commitment to invoke fire together with smoke, we can act appropriately in the presence of fire when we become aware of smoke. The resulting awareness is dependent upon the warrantable relation of the elements in the inference becoming cognitively significant. ${ }^{18}$

The concepts invoked in making a conceptual commitment are not fully formed independent of their use in cognition. Instead, the contents of concepts are shaped by the commitment one undertakes through inferential cognition. It is by making a conceptual commitment that we acquire knowledge. In turn, the triple conditions which hold between the elements of inference become incorporated into cognition.

As the content of a concept becomes more determinate, it is assumed that one may come to recognise more robust relations between smoke and fire. The more one learns about smoke (its chemical constitution, etc.), the better one ascertains its relation to fire. Of course, there may be a situation where we may have to revise our commitment about smoke and fire. If one thought that smoke is just something caused by cooking, for example, then one might have to revise one's epistemic commitment so that one would now be aware that smoke is something which is caused by fire. So an inferential cognition may defeat the inferential cognition that forms the content of smoke in its premature form (when one wasn't aware that smoke is caused by fire and not by cooking as such). ${ }^{19}$ In this way, as the content of concepts becomes more determinate through inferential cognitions, one attains more certainty as well as truth of the matter and, thus, acquires warranted awareness.

Now, it is true that an inferential cognition requires awareness of triple conditions which can be given a formal treatment:

\footnotetext{
${ }^{18}$ The Buddhist theory of concepts and concept formation is what is known as the theory of apoha. For the most recent study of apoha, see Siderits, Tillemans and Chakrabarti (2011).

${ }^{19}$ For a discussion of the defeasible nature of triple conditions, see Oetke (1996).
} 
Inferential reason (hetu) must be (known to be) present in the locus in question (sapaksa).

Inferential reason must be (known to be) present in at least one similar case (sapakșa).

Inferential reason must not be (known to be) present in any dissimilar case (vipakșa).

One can provide mathematical structures that satisfy these triple conditions as a study of Buddhist 'logic'. ${ }^{20}$ They may express the forms that inferential cognition may take. Nonetheless, for Buddhist logicians, inference is considered to be important insofar as it shapes the contents of our awareness. That is, the importance of inference lies not in ascertaining forms of knowledge but in their contribution to the content of knowledge. It is in this way that we can see an understanding of the nature of inferential cognition as a crucial aspect of Buddhist epistemology as well as the conception of inference (and logic more generally) that can be attributed to Buddhist logicians.

\section{Logic in Buddhist Logic}

If we thought that logic was essentially formal, the notions of inference and inferential cognitions must be assumed to come apart in a certain way. An inference might be said to underwrite the validity of an inferential cognition. Yet it would not impel one to undergo an inferential cognitive process. According to the formal conception of logic, an inference expresses the fact about the validity of an inferential cognition, but it doesn't express the norm by means of which an inferential cognition ought to take place. Thus, under the formal conception of logic, an inferential cognition must be understood as independent of inferences.

Buddhist logicians, by contrast, don't think of inferential cognitions as independent of inferences. An inference expresses an epistemic commitment that forms the content of a warranted awareness. This means that Buddhist logicians don't think of inference as underwriting an inferential cognition. Rather, an inference is considered to express an epistemic commitment, particularly a conceptual commitment, that is undertaken in an inferential cognitive process. For Buddhist logicians, the significance of inference lies within the context of inferential cognitions.

Thus, the Buddhist study of inference (anumāna) is not a formal study of arguments. Buddhist logicians are not concerned with abstracting forms of arguments and studying the (mathematical) properties of these forms. While one might take

\footnotetext{
${ }^{20}$ For a book-length study of Buddhist logic in terms of mathematical structures, see Chi (1969).
} 
this as an evidence for the thought that there is no Buddhist logic, one might alternatively attempt to understand the role of inference according to a conception of logic that does not abstract from the contents of knowledge. ${ }^{21}$ As I have attempted to show, we can recognise the logical significance of inference as understood by Buddhist logicians despite the fact that its logical significance lies within the context of (contentful) cognition.

\section{References}

Arnold, Dan (2005) Buddhists, Brahmins, and Belief - Epistemology in South Asian Philosophy of Religion, New York: Columbia University Press.

Carroll, Lewis (1895) 'What the Tortoise said to Achilles', Mind, Vol. 4, pp. 278-280.

Chi, R.S.Y (1969) Buddhist Formal Logic, London: The Royal Asiatic Society of Great Britain.

Dreyfus, Goerges B.J. (1997) Recognizing Reality - Dharmakìrti's Philosophy and Its Tibetan Interpretations, Albany, NY: State University of New York Press.

Dunne, John D. (2004) Foundations of Dharmakīrti's Philosophy, Boston: Wisdom Publications.

Franco, Eli (1990) 'Valid Reason, True Sign', Wiener Zeitschrift für die Kunde Südasiens, Vol. 34, pp. 189-208.

Garfield, Jay and Graham Priest (2003) 'Nāgārjuna and the Limits of Thought', Philosophy East $\mathcal{E}$ West, Vol. 53, pp. 1-21.

Gillon, Brendan (2011) 'Logic in Classical Indian Philosophy', The Stanford Encyclopedia of Philosophy (Summer 2011 Edition), Edward N. Zalta (ed.), URL = $<$ http://plato.stanford.edu/archives/sum2011/entries/logic-india/>.

Goldfarb, Warren (1979) 'Logic in the Twenties: The Nature of the Quantifier', The Journal of Symbolic Logic, Vol. 44, pp. 351-368.

Harman, Gilbert (1986) Change in View, Cambridge, MA: MIT Press.

Hattori, Massaki (1968) Dignāga, On Perception, Cambridge, MA: Harvard University Press.

Hayes, Richard (1988) Dignāga on the Interpretation of Signs, Dordrecht: Kluwer Academic Publishers.

Hylton, Peter (2005) Propositions, Functions, and Analysis, Oxford: Clarendon Press.

Katsura, Shoryu (1983) 'Dignāga on Trairūpya', Journal of Indian and Buddhist Studies, Vol. 32, pp. 15-21.

_ (1984) 'Dharmakīti's Theory of Truth', Journal of Indian Philosophy, Vol. 12, pp. 215235.

Katsura, Shoryu and Ernst Steinkellner (eds.) (2004) The Role of the Example (Drștānta) in Classical Indian Logic, Vienna: Arbeitskreis für Tibetische und Buddhistische Studien Universität Wien.

Kellner, Birgit (2004) 'First logic, then the Buddha?', Hōrin, Vol. 11, pp. 147-167.

Krasser, Helmut (2001) 'On Dharmakīrti's Understanding of Pramāna-bhūta and His Definition of Pramāna’, Wiener Zeitshcrift für die Kunde Südasiens, Vol. 45, pp. 173-199.

\footnotetext{
${ }^{21}$ After a careful investigation into the (western) history of logic, one becomes aware that it is a mistake to think that there is only one way to understand the nature of logic. See, for example, MacFarlane (2000). I think that it is equally mistaken to think that there is no Buddhist logic simply because Buddhist logicians are not concerned with the forms of arguments independent of what the arguments are about.
} 
Macbeth, Danielle (2005) Frege's Logic, Cambridge, MA: Harvard University Press.

MacFarlane, John G. (2000) What Does It Mean To Say That Logic Is Formal?, Ph.D Dissertation, University of Pittsburgh.

Matilal, Bimal Krishna (1998) The Character of Logic in India, Jonardon Ganeri and Heeraman Tiwari (eds.), Albany, NY: State University of New York Press.

Mohanty, Jitendranath (1992) Reason and Tradition in Indian Thought - An Essay on the Nature of Indian Philosophical Thinking, Oxford: Clarendon Press.

Oetke, Claus (1994a) Studies on the Doctrine of Trairūpya, Wiener Studien zur Tibetologie und Buddhismuskunde, Vol. 33, Vienna: Arbeitskreis für Tibetische und Buddhistische Studien Universität Wien.

_ (1994b) 'Praśastapāda's Views on the 'Antinomic Reason' and Their Consequences for a Theory of Default Reasoning', Asiatische Studien/Études asiatiques, Vol. 48, pp. 845-866.

_ (1996) 'Ancient Indian Logic as a Theory of Non-Monotonic Reasoning', Journal of Indian Philosophy, Vol. 24, pp. 447-539.

Patil, Parimal G. (2009) Against a Hindu God - Buddhist Philosophy of Religion in India, New York: Columbia University Press.

- (2010) 'History, Philology, and the Philosophical Study of Sanskrit Texts', Journal of Indian Philosophy, Vol. 38, pp. 163-202.

Potter, Karl (1969) 'Dignāga and the Development of Indian Logic', In Chi (1969), pp. xliiixlviii.

Priest, Graham (2010) 'The Logic of the catuskoti', Comparative Philosophy, Vol. 1, pp. 24-54.

Priest, Graham and Koji Tanaka (2009) 'Paraconsistent Logic', The Stanford Encyclopedia of Philosophy (Summer 2009 Edition), Edward N. Zalta (ed.), URL = $<$ http://plato.stanford.edu/archives/sum2009/entries/logic-paraconsistent/>.

Robinson, Richard (1957) 'Some Logical Aspects of Nāgārjuna's System', Philosophy East $\mathcal{E}$ West, Vol. 6, pp. 291-308.

Ruegg, D. Seyfort (1977) 'The Uses of the Four Positions of the catuskoti and the Problem of the Description of Reality in Mahāyāna Buddhism', Journal of Indian Philosophy, Vol. 5, pp. 1-71.

Siderits, Mark (2003) 'Deductive, Inductive, Both or Neither?', Journal of Indian Philosophy, Vol. 31, pp. 303-321.

Siderits, Mark, Tom Tillemans and Arindam Chakrabarti (eds.) (2011) Apoha - Buddhist Nominalism and Human Cognition, New York: Columbia University Press.

Steikellner, Ernst (1998) 'Dharmakīrti', The Routledge Encyclopedia of Philosophy, E. Craig (ed.), London: Routledge, pp. 51-53.

Tarski, Alfred (1936) 'O pojeciu wynikania logicznego' (On the Concept of Logical Consequence), Przeglad Filozoficzny, Vol. 39, pp. 58-68, an English translation by J.H. Woodger in Logic, Semantics, Metamathematics (Second Edition), John Corcoran (ed.), Indinapolis: Hackett Publishing Company, 1983.

Tillemans, Tom J.F. (1999) Scripture, Logic, Language: Essays on Dharmakīrti and His Tibetan Successors, Boston: Wisdom Publications.

(2009) 'How Do Mādhyamikas Think?: Notes on Jay Garfield, Graham Priest, and Paraconsistency', Pointing at the Moon - Buddhism, Logic, Analytic Philosophy, Oxford: Oxford University Press, pp. 83-99.

— (2004) 'The Slow Death of the trairūpya in Buddhist Logic: A Propose of Sa skya Pandita', Hōrin, Vol. 11, pp. 83-93.

— (2011) 'Dharmakīti', The Stanford Encyclopedia of Philosophy (Fall 2011 Edition), Ed- 
ward N. Zalta (ed.), URL $=<$ http://plato.stanford.edu/archives/fall2011/entries/dharmaki$\mathrm{rti} />$.

van Heijenoort, Jean (1967) 'Logic as Calculus and Logic as Language', Synthese, Vol. 17, pp. 324-330.

Young, J. Michael (1992) Lectures on Logic, Cambridge: Cambridge University Press. 